\title{
Rapid Synthesis of Oligosaccharides Based on One-Pot Glycosylation
}

\author{
ワンポットグリコシル化反応を基盤とする糖鎖迅速合成法の開発 \\ Tanaka, Hiroshi; Yamada, Haruo; and Takahashi, Takashi \\ Department of Applied Chemistry, Graduate School of Science and Engineering, Tokyo Institute of Technology, 2-12-1 \\ Ookayama, Meguro, Tokyo 152-8552, Japan \\ FAX: +81-3-5734-2884, E-mail: thiroshi@apc.titech.ac.jp
}

Key Words: combinatorial chemistry, labo automation, parallel synthesis, glycosylation

\begin{abstract}
In this study, biologically active oligosaccharides were synthesized based on one-pot glycosylation. Onepot glycosylation enables direct coupling of multisaccharide building blocks via sequential chemo- and regioselective glycosylations in a single vessel. A di-branched heptasaccharide was synthesized by one-pot glycosylation using seven independent building blocks. The glycosyl amino acids containing sialic acids were covered by the onepot glycosylation, in which sialylation was achieved with $\mathrm{N}$-Troc-protected thiosialoside. Combinatorial oligosaccharide libraries were synthesized by one-pot glycosylation using parallel and automated synthesizers. This study also developed a polymer-assisted strategy for deprotection of protected oligosaccharides.
\end{abstract}

\section{A. Introduction}

Oligosaccharides play important roles in cell surface events via carbohydrate-protein and carbohydrate-carbohydrate interactions (1). The ability to chemically synthesize structurally defined oligosaccharides for structure-function studies is highly advantageous because oligosaccharides from natural sources are available only in limited quantities. Recent progress in oligosaccharide synthesis has resulted in a number of new and efficient glycosidation methodologies (2). However, oligosaccahride syntheses involving glycosylation and deprotection are difficult to achieve using standard protocols and require well-trained organic chemists. Seeberger and co-workers reported an automated solid-phase oligosaccharide synthesis using a modified solid-phase peptide synthesizer (3). Alternatively, one-pot sequential glycosylation for the synthesis of oligosaccharides was demonstrated by Kahne and co-workers in 1993. In this method an $\alpha$-linked deoxytrisaccahride was prepared by sequential chemoselective activation of glycosyl sulfoxide and thioglycoside using a single activator (4). One-pot glycosylation enables coupling of multiple building blocks in a single vessel to yield oligosaccharides; the reaction protocols are simple, involving
要 約

本総説では、当研究室にて、研究してきたワンポットグリ コシル化反応を利用した生物活性糖鎖の合成研究について述 ベる。ワンポットグリコシル化反応は、連続的な化学および、 位置選択的なグリコシル化反応を同一反応容器内で行なうこ とにより、多種類の糖鎖合成ユニットより、オリゴ糖を一挙 に合成する手法である。本手法を利用することにより、7つ の独立な糖鎖ユニット利用した分岐 7 糖のワンポット合成が 可能である。また、シアル酸を含む糖アミノ酸の合成も可能 である。シアル酸含有糖鎖の合成では、シアル酸の 5 位のア セトアミド基を N-T r o c 基で置換したシアル酸糖供与体を利用 した。また、ワンポットグリコシル化反応と並列液相自動合 成装置を利用することにより、糖鎖のコンビナトリアルライ ブラリーの自動合成を達成した。さらに、得られた保護糖鎖 の効率的な脱保護法として、固相脱保護法についても合わせ て報告する。

\section{はじめに}

糖鎖は、糖鎖 - タンパク質や、糖鎖 - 糖鎖相互作用を介し て、樣々な細胞表層の生物学的イベントにおいて重要な役割 を果たしている(1)。糖鎖は単離精製が困難で、かつ、分離困 難な不純物が含まれている場合が多いため、兰れらの構造活 性相関の研究では、化学合成によって得られた純粋なオリゴ 糖を利用することが望まれている。近年の糖鎖合成法の格段 の進歩により、樣々な新しくかつ効率良いグリコシル化方法 が開発されている (2)。しかし、グリコシル化反応および、脱 保護を含む糖鎖合成を画一化された操作で行なうことは難し く、多くの場合、よく熟練した糖鎖合成化学者のを必要とする。 近年、Seebergerらによって、ペプチド合成装置を改良した合 成装置を利用することにより、糖鎖の固相合成が可能である ことが示されている(3)。一方、1993年にKahneらによって、 ワンポットグリコシル化反応による $\alpha$ デオキシ 3 糖の効率的 合成が報告された。本手法では、スルホキシド糖とチ才糖の 一つ活性化剂による連続的な活性化により 3 糖のワンポット 合成を行なっている (4)。ワンポットグリコシル化反応は、試 薬および、基質の連続的な導入という簡単な操作で、複数の 糖鎖ユニットを結合させ、一つの反応容器内でオリゴ糖の合 成を可能にする。我々は、本手法が、通常の糖鎖に応用でき るのであれば、糖鎖の合成法として非常に有用な方法になる 
sequential addition of reagents and substrates. Adaptation of the method to the synthesis of conventional oligosaccharides would be an effective and attractive way of producing various oligosaccharides. In this study, biologically important oligosaccharides were synthesized using one-pot glycosylation and a polymer-assisted strategy for deprotection of protected oligosaccharides was developed.

\section{B. One-Pot Glycosylation}

Scheme 1 shows two basic types of one-pot sequential glycosylation. The first is linear one-pot glycosylation, involving chemo-selective glycosylation that yields linear oligosaccharides. The second is branched one-pot glycosylation which involves regio-selective glycosylation to yield branched oligosaccharides. Ley and co-workers reported a one-pot glycosylation using multiple glycosyl donors whose reactivity was controlled by protecting group selection (5). Wong and co-workers developed the Optimer method: sequential activation of reactivity-tuned thioglycosides (6). However, protecting groups on saccharide units greatly influence stereo-selectivity, as well as reactivity, during glycosidation reactions. In contrast, chemo-selective activation of glycosyl donors with different leaving groups (7, $8,9)$ was the approach used in the present study. Reactivity of saccharide units toward glycosidation was tuned using appropriate activators. This method may be amenable to various types of chemo- and stereo-selective glycosylation and may be effective in the synthesis of oligosaccharide libraries.

Scheme 2 shows a one-pot synthesis of branched and linear trisaccharides, using glycosyl bromides, thioglycosides and 2-bromoethyl glycosides (10). Glycosylation of the thioglycoside 2 with the glycosyl bromide 1 by AgOTf, followed by activation of the remaining glycosylated thioglycoside 4 with NIS/TfOH in the presence of acceptor
と期待した。本論文では、ワンポットグリコシル化反応を利 用した生物活性糖鎖の合成と固相法を利用した保護糖鎖の簡 便脱保護法について述べる。

\section{B. ワンポットグリコシル化反応}

スキーム 1 にワンポットグリコシル化反応の 2 つの基本 反応を示す。一つは、化学選択的グリコシル化反応を含む直 鎖型ワンポットグリコシル化反応である。もう一つは、位置 選択的なグリコシル化反応を含む分岐型のグリコシル化反応 である。Ley らは、反応性を保護基により調整した糖供与体を 利用する化学選択的グリコシル化によるワンポットグリコシ ル化反応を報告している (5)。また、W ong らは、反応性を制 御したチ才糖の連続的活性化を基盤としたOpitimer 法を報告 している (6)。しかしながら、糖鎖の保護基は、糖鎖の反応性 だけでなく、グリコシル化反応の立体選択性にも大きく影響 する。一方、我々は、異なる脱離基を有する糖供与体に対し て適切な活性化剂を選択することにより、光の反応性を制御 した化学選択的グリコシル化反応によるワンポットグリコシ ル化反応に着目した (7、8、9)。脱離基と活性化剂の組み合わ せによる連続的なグリコシル化は、樣々なタイプの化学及び 立体選択的なグリコシル化反応を可能にし、糖鎖ライブラリー 合成に有用であると考えた (スキーム 1)。

スキーム 2 に、ブロモ糖、チ才糖および、2 - ブロモエチ ルグリコシドを用いる分岐型および、直鎖型ワンポットグリ コシル化を示す (10)。反応操作を以下に示す。直鎖型ワンポッ トグリコシル化反応では、銀トリフレートを用いてブロモ糖 1 を活性化しチオ糖 2 にグリコシル化することにより、グリコ シル化されたチ才糖 4 を合成する。続いて NIS $/ \mathrm{fOH}$ を用いて、

Linear type one-pot glycosylation
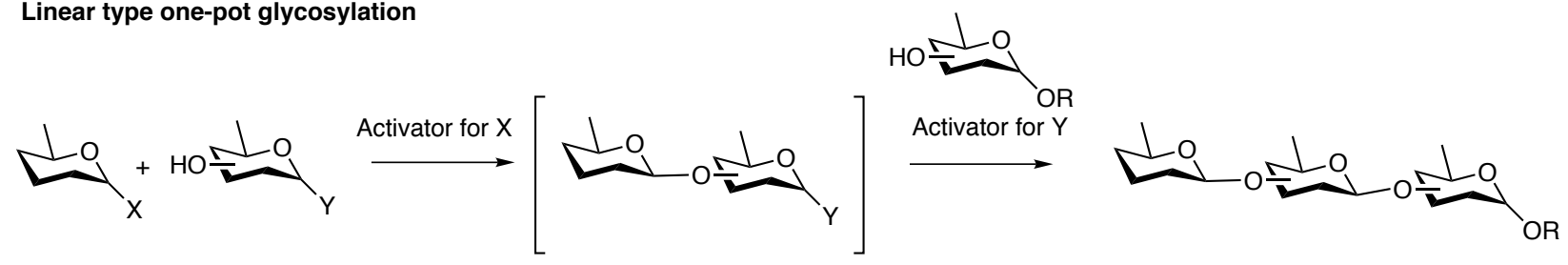

Branched type one-pot glycosylation

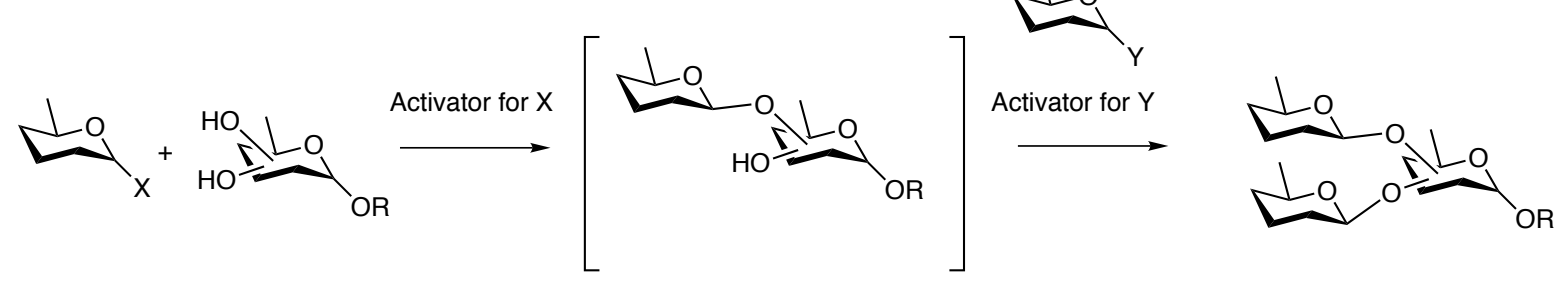

Scheme 1. Two types of one-pot glycosylation: linear and branched. 

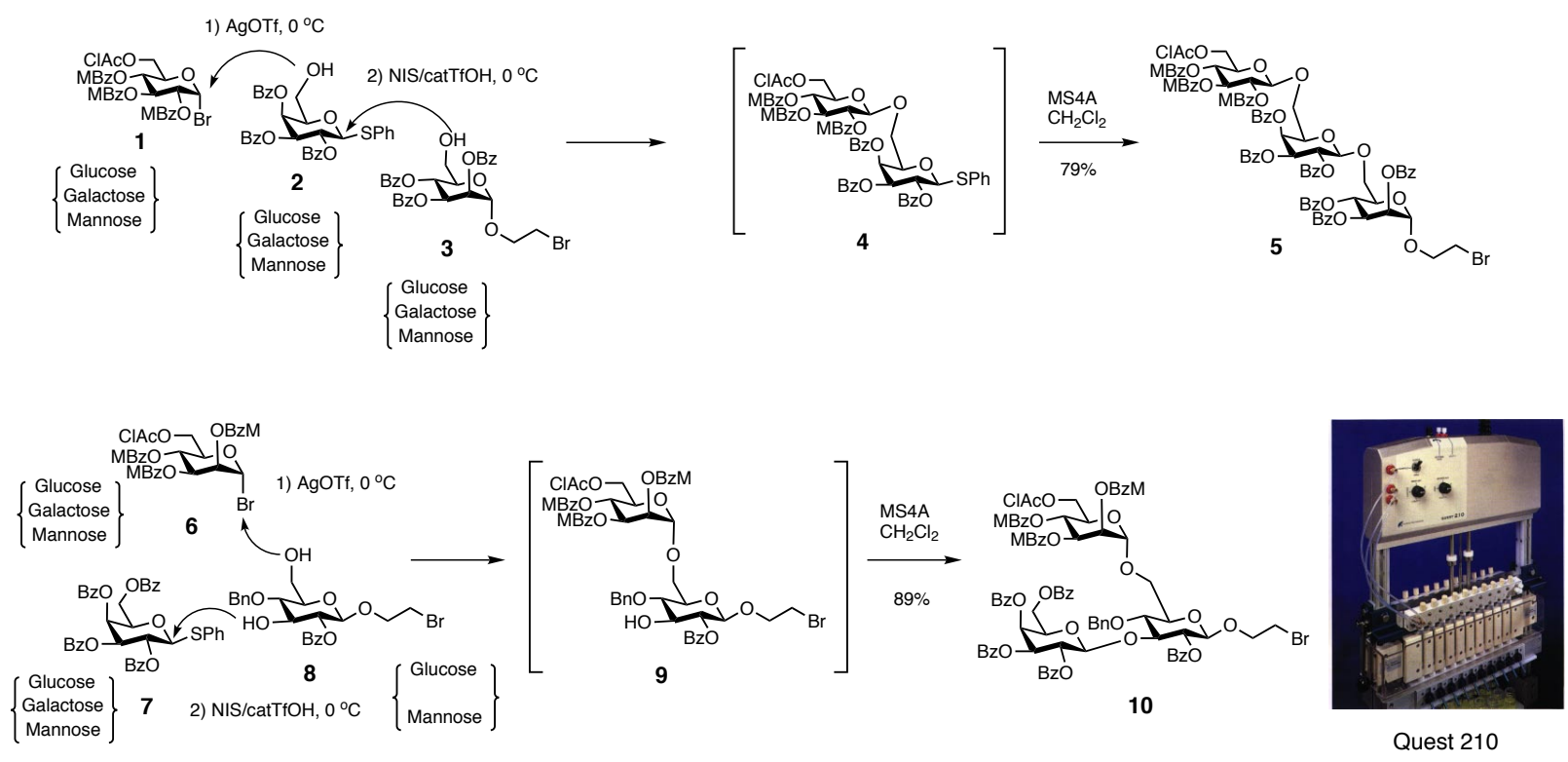

Scheme 2. Synthesis of trisaccharide using a linear and a branched one-pot glycosylation.

3 provided the linear trisaccharide 5 . Regio-selective glycosylation of the primary alcohol at the 6 position of the 3,6 dihydroxyl glycosyl acceptor 8 with the glycosyl bromide 6 , followed by subsequent glycosylation of the remaining secondary alcohol of 9 with thioglycoside provided the branched trisaccharide 10. This method allowed for the use of various combinations of glycosyl bromides and thioglycosides and 2-bromoethyl glycosides prepared from glucose, galactose and mannose in the synthesis of oligosaccharide libraries. However, a 3,6 dihydroxyl galactoside unit was not suitable for this approach due to the small difference in reactivity toward glycosylation between hydroxyl groups at the 3 and 6 positions. A parallel synthetic apparatus (Quest 210) was effective for the synthesis of an oligosaccharide library. The oligosaccharide library subsequently was used in the synthesis of glycol-conjugated, 9-member, DNA-cleaving molecules $(11,12,13)$.

C. Applications of One-Pot Glycosylation to the Synthesis of bBiologically Active Oligosaccharides

C-1. One-Pot Synthesis of Branched Oligosaccharides Possessing a Phytoalexin-Elicitor Activity in Soybeans

The hexa- $\beta$-glucopyranosyl-D-glucitol (11), which is a $\beta$-glucan fragment, exhibits phytoalexin-elicitor activity in soybeans (Scheme 3) (14). The hexasaccharide unit composed of the $\beta(1,3)$ diglucosyl $\beta(1,6)$ tetraglucoside is the minimum structural element for high elicitor activity. Scheme 3 shows a one-pot synthesis of the methyl hexasaccharide $\mathbf{1 2}$ involving chemo-selective glycosylation of the thioglucoside $\mathbf{1 4}$ at the 6 position with the 3,6-diglucosylatd glucosyl imidate $\mathbf{1 3}$ and subsequent glycosidation of the remaining thioglycoside at the
生成したチ才糖 4 を活性化し、グリコシル化することにより 目的とする直鎖 3 糖 5 をワンポットで得た。一方、分岐型ワ ンポットグコシル化反応では、3、6位に2つの水酸基を有す る糖受容体 8 を用いて、まず、6 位選択的にブロモ糖 6 をグ リコシル化し二糖 9 を合成し、残った 2 級水酸基にチ才糖 7 を連続的にグリコシル化することにより分岐 3 糖 10 をワン ポットで得た。本手法を利用して、グリコース、ガラクトース、 マンノースより構成される分岐および、直鎖 3 糖ライブラリー の合成を行なった。光の際、合成効率化のために、アルゴノー 卜社製の並列合成装置 Quest210を用いた。ただし、ガラクトー スをアクセプターとして用いる分岐型ワンポットグリコシル 化反応は、ガラクトースの3、6 位の水酸基の反応性の差が十 分でないため達成できていない。なお、得られた糖鎖ライブ ラリーは、9 員環 DNA 切断分子と結合させ、配糖体型 DNA 切断分子ライブラリーの合成に利用した $(11,12,13)$ 。

C. ワンポットグリコシル化反応を利用した生物活性糖鎖の合 成

C-1. 大豆ファイトレキシンエリシター糖鎖のワンポット 合成

$\beta$ グルカンの部分構造である還元糖を還元末端に有する 6 糖 11 は、大豆のファイトレキシンエリシターとして知られ ている (14)。2つの $\beta(1,3)$ グリコシドを有する $\beta(1,6) 4$ 糖か らなる 6 糖部が、弚の活性発現最小単位である。スキーム 3 に、 3 成分ワンポットグリコシル化反応による 6 糖 12 の合成を示 す (15)。本合成では、3 糖イミダート糖供与体 13 のチ才糖 14 への化学選択的グリコシル化反応、続く、二糖糖受容体 15 人 の連続的なグリコシル化反応により分岐 6 糖 16 を合成する。 

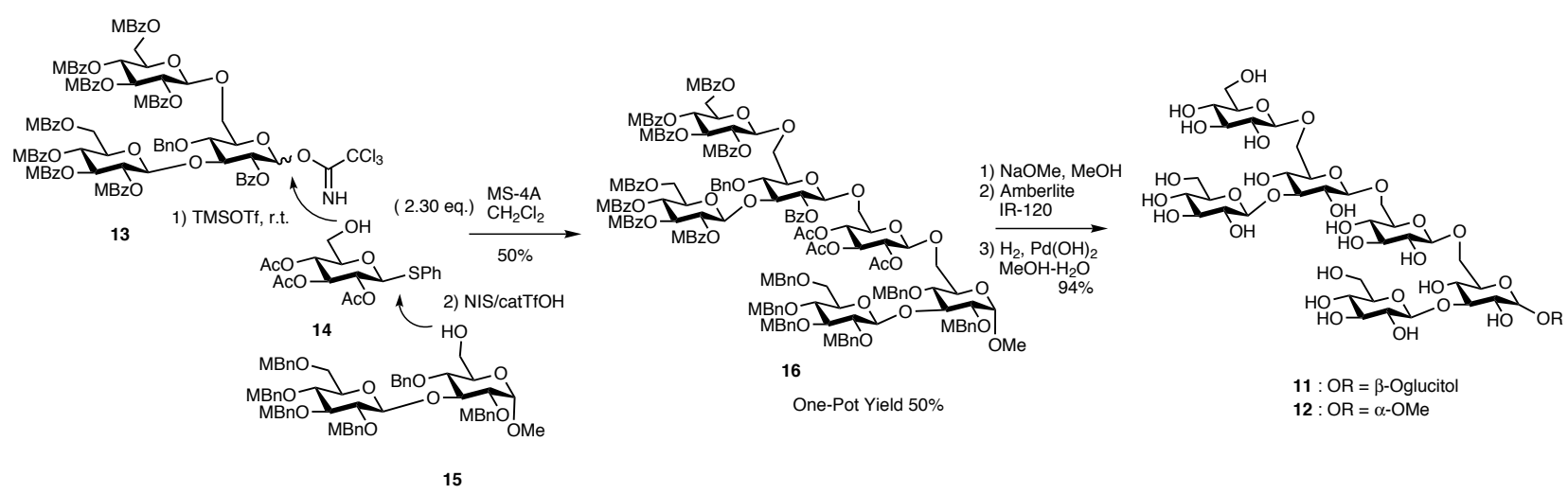

\section{Scheme 3. The synthesis of the branched hexasaccharide 12 by one-pot sequential glycosylation.}

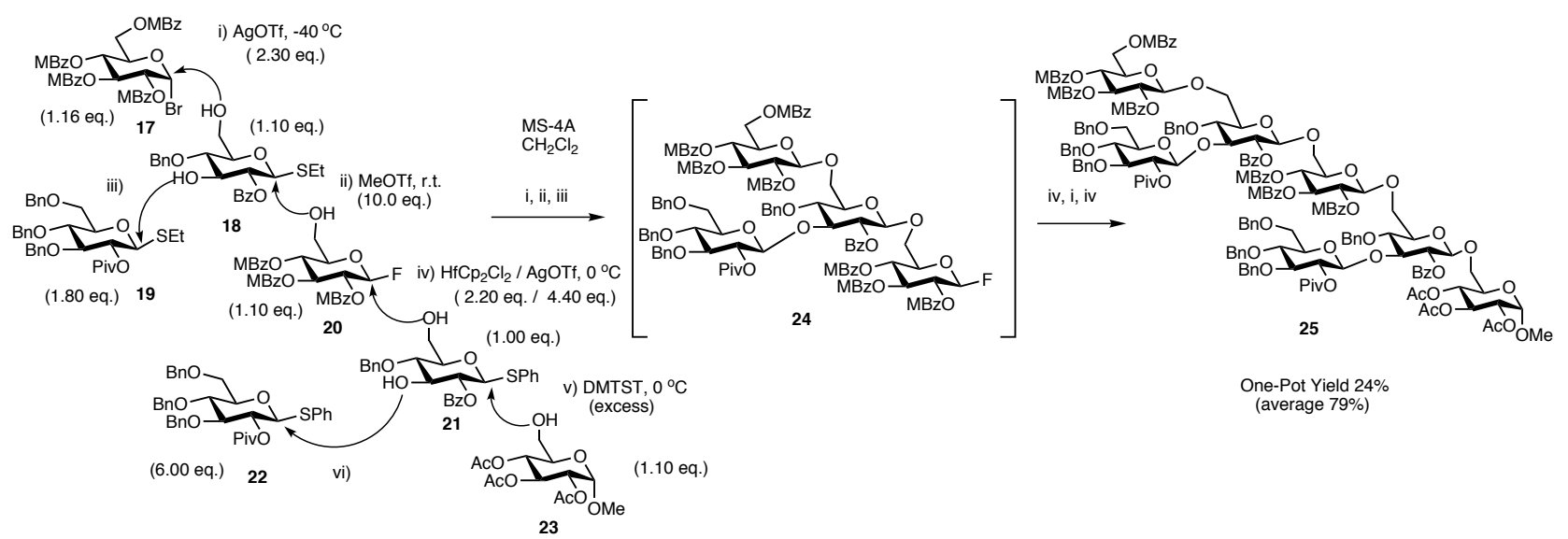

Scheme 4. The synthesis of the branched heptasaccharide 25 by one-pot sequential glycosylation.

primary alcohol of the disaccharide acceptor $\mathbf{1 5}$ in one-pot (15). Imidate and sulfanyl groups were effective in chemo-selective glycosylation of glucoside with 3,6-diglucosyl glucoside. TMSOTf, which was used to activate glycosyl imidate, did not prevent activation of the thioglycoside.

Linear- and branched-type one-pot glycosylations using more than two leaving groups in a reaction sequence allowed the one-pot synthesis of more complex branched oligosaccharides from simple building blocks (16). Scheme 4 shows a one-pot synthesis of the di-branched heptasaccharide $\mathbf{2 5}$ from seven independent building blocks possessing four different leaving groups (17). The glycosyl bromide 17, ethyl glycosides $\mathbf{1 8}$ and 19, glycosyl fluoride $\mathbf{2 0}$ and phenylthioglycosides $\mathbf{2 1}$ and $\mathbf{2 2}$ were activated in this sequence. The reaction sequence involved three steps: (i) regio-selective glycosylation of the primary alcohol of ethylthioglycoside 18 with the glycosyl bromide $\mathbf{1 7}$ in the presence of the secondary alcohol; (ii) glycosylation of the glycosyl fluoride 20; and ,(iii) glycosylation of the remaining secondary alcohol with thioglycoside $\mathbf{1 9}$ to give the tetrasaccharide 24. A successive one-pot glycosylation starting
イミダート糖の活性化剂であるTMSOTf は、続くチ才糖の活 性化を阻害しない点が重要である(スキーム3)。

2 つ以上の脱離基を利用した直鎖型および、分岐型ワン ポットグリコシル化反応を組み合わせることにより、より複 杂隹な糖鎖の合成の簡便合成が可能になる (16)。スキーム4 4 は、 4 つの異なる脱離基を利用した 7 つの独立な糖ユニットの結 合を含む 2 分岐 7 糖 $\mathbf{2 5}$ の合成を示す (17)。本合成では、ブ ロモ糖 17、エチルチ才糖 18、19、フッ化糖 20、フェニルチ才 糖 21、22 の連続的活性化を利用した。反応の順序は以下の通 りである。まず、3、6 位に水酸基を有するエチルチ才糖 18 の 6 位に、ブロモ糖 17 を銀トリフレートで活性化して、位選 択的および、化学選択的にグリコシル化を行なった。続いて、 エチルチオ糖をメチルトリフレートを用いて活性化し、フッ 化糖 20 の6 位にグリコシル化した。続いて、残った 3 位水酸 基にエチルチオ糖 19 をグリコシル化することにより分岐 4 糖

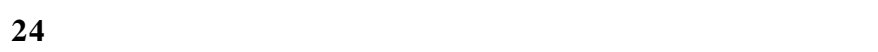


with the tetrasaccharide $\mathbf{2 4}$ using three saccharide building blocks 21, 22 and 23 (iv, v and vi) allowed the one-pot heptasaccharide synthesis using four different leaving groups. All of the glycosylations proceeded in a $\beta$-stereoselecitive manner via neighboring group participation of the $\mathrm{C} 2$ acyl protecting groups. The one-pot six-step glycosylation was achieved utilizing a parallel synthesizer (Quest 210), which was effective for the synthesis of an oligosaccharide library.

\section{C-2. Synthesis of Core 2 Class Gycosyl Amino Acids by One-Pot Glycosylation}

$\operatorname{Gal} \beta(1 \rightarrow 3)$-[GlcNAc $\beta(1 \rightarrow 6)]$-GalNAc $\alpha(1 \rightarrow 3)$-Ser and $-\operatorname{Thr}$ (26a and 26b), which are classified as core 2 class glycosyl amino acids, comprise mucin-type glycoproteins (Scheme 5). Glycosyl amino acids are important building blocks in the synthesis of glycopeptides and glycoproteins. Scheme 5 shows the synthesis of core 2 class glycosyl amino acids by one-pot three-step sequential glycosylation (18). Chemo-selective glycosylation of the trimethysilyl ether on the 2-azido-6- $O$-trimethylsilyl-3-hydroxythioglycoside $\mathbf{2 8}$ with the glycosyl fluoride $\mathbf{2 7}$ was achieved by stoichiometric treatment with $\mathrm{BF}_{3} \cdot \mathrm{OEt}_{2}$. Subsequent glycosidation of the galactosyl fluoride 30, followed by glycosidation of the resulting thioglycoside at the amino acids 31a and $\mathbf{3 1 b}$ provided the protected core 2 class glycosyl amino acids 32a and 32b. Use of the dihydroxyl acceptor 29 instead of the silylether $\mathbf{2 8}$ resulted in a mixture of the disaccharide $\mathbf{3 3}$, trisaccharide $\mathbf{3 4}$ and thioglycoside $\mathbf{3 5}$. The thioglycoside 35 was generated by aglycone transfer via $36(19,20)$. The silicon-fluoride interaction between donor and acceptor prevented these undesired reactions in glycosylation of the silylether $\mathbf{2 8}$ with the glycosyl fluoride 27. (21)
糖 21,22 および、メチルグリコシド 23 を利用して連続的に行 なうことにより、目的とする分岐 7 糖 25 のワンポット合成を 達成した。なお、すべてのグリコシル化反応は、2 位のアシ ル保護基の隣接基効果により、 $\beta$ 選択的に進行した。このワ ンポットグリコシル化反応は、先に述べた並列自動合成装置 を利用しても実施可能であり、ライブラリー合成に有用な手 法であること明らかにした (スキーム 4$)$ 。

C-2. コア 2 型糖アミノ酸のワンポット 合成

Galb(1 $\rightarrow$ 3)-[GIcNA cb(1 $\rightarrow$ 6)]-GalNA ca( $1 \rightarrow 3)$-Ser and -Thr (26a and 26b) は、コア2 クラスと呼ばれる糖アミノ酸ユニッ トで、ムチン型の糖タンパク質に見られる。このアミノ酸ユ ニットは、糖ペプチドや糖タンパク質の化学合成における有 用な中間体となる。スキーム 5 では、このコア 2 クラスの糖 アミノ酸ユニットのワンポット合成を示す (18)。6 位をトリメ チルシリル基で保護した 2 アジドチオ糖 28 に対し、量論量の $\mathrm{BF}_{3} \cdot \mathrm{OEt}_{2}$ を用いて活性化させたフッ化糖 27 を作用させたと ころ、位置及び化学選択的に 6 位にグルコサミンが導入され たチ才糖 33 を得た。続いて、残った 3 位水酸基にガラクトシ ド 30 をグリコシル化し、最後に、セリン 31a、または、スレ オニン $31 \mathrm{~b}$ に対しグリコシル化することにより、目的とする 糖アミノ酸ユニット 32a と 32b のワンポット合成に成功した。 ここで、3、6ジヒドロキシル体 29 を用いてグリコシル化反 応を行なうと、目的とする二糖 $\mathbf{3 3}$ だけでなく、3 位にもグリ コシル化された 3 糖 34、また、チオニウムカチオン $\mathbf{3 6}$ を経由 したアグリコン転位反応により生成したと考えられるチ才糖 35 の生成を確認した $(19,20)$ 。フッ化糖 27 のシリルエーテル 28 へのグリコシル化反応では、シリコンーフッ素の相互作用 によりシリルエーテルへの選択的なグリコシル化反応が進行 し、これらの副反応を抑制したと考えている(21) (スキーム5)。

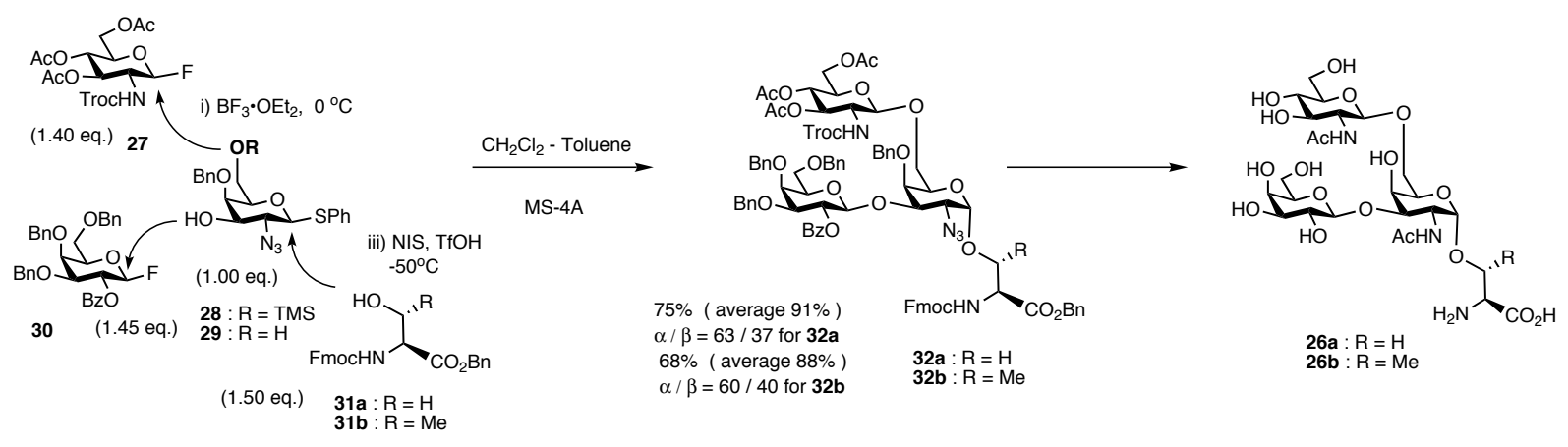

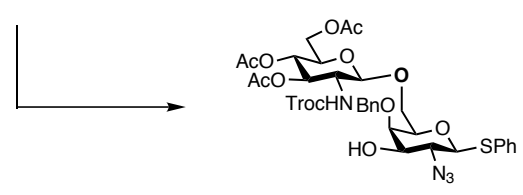

33

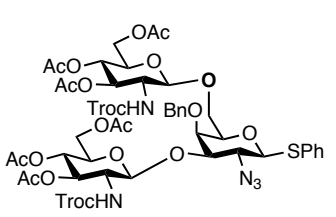

34

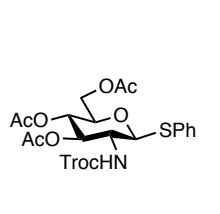

35

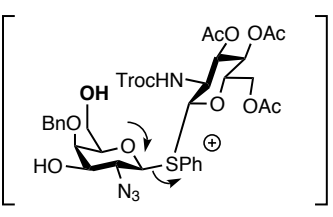

36

Scheme 5. The synthesis of the glycosyl amino acids by one-pot sequential glycosylation. 


\section{C-3. Synthesis of Sialo-Containing Glycosyl Amino Acids by One-Pot Glycosylation}

Sialic acids, such as Neu5Ac, Neu5Glc and KDN, are often located at the non-reducing end of glycoconjugates on the cell surface through $\alpha$-glycosidic bonds, and play a central role in cell surface recognition phenomena. Adaptation of sialylation to one-pot glycosylation, would be an effective and attractive way to synthesize sialo-containing oligosaccharides. However, $\alpha$-selective sialylation is a problematic step in the chemical synthesis of oligosaccharides. Recently, it was found that replacement of the acetylamino group at the 5 position of the sialyl donor with an $N, N$-diacetyl (22), azido (23), $N$-TFA (24), $N$-Troc $(25,26), N$-Fmoc (26), $N$-trichloroacetyl (26), or $N$-phthalimide (27) group is effective for direct $\alpha$-selective sialylation. Scheme 6 shows our results from the glycosylation of the primary alcohol $\mathbf{3 8}$ with the sialyl donors $\mathbf{3 7} \mathbf{a}-\mathbf{i}$, varying the $N$-protecting group at the 5 position. (26). The $N$-Fmoc and $N$-Troc $\beta$-thiophenyl sialosides $37 \mathbf{d}$ and $37 \mathbf{e}$ are suitable for the synthesis of glycosyl amino acids and glycopeptides because they can be modified to $\mathrm{N}$-acetyl groups without racemization of amino acids. Scheme 7 shows a one-pot synthesis of sialo-containing glycosyl amino acids $\mathbf{4 1}$ using the $\mathrm{N}$-Troc sialyl donor 37e. Chemo-selective glycosylation of the galactosyl fluoride $\mathbf{4 2}$ with the $N$-Troc-protected thiosialoside 37e, followed by glycosylation of galactosaminyl serine $\mathbf{4 3}$ provided the linear trisaccharide $\mathbf{4 1}$ in one-pot (26b). The $\alpha(2,3)$ sialylation of galactosyl fluoride proceeded smoothly to provide the sialyl galactosyl fluoride $\mathbf{4 4}$. This chemo-selective sialylation method was useful for synthesizing building blocks

\section{C-3. シアル酸含有糖アミノ酸のワンポット 合成}

シアル酸 (Neu5A c, Neu5GIc, KDN) に代表されるシアル 酸は、 a グリコシド結合を介し細胞表層の糖鎖の非還元末端 に多く見られる。さらに、細胞表層でおこる細胞間相互作用 に重要な役割を果たしている。もし、シアリル化がワンポッ トグリコシル化反応に組み込むことが可能であれば、弚の手 法は、樣々なシアル酸含有糖鎖を合成する方法として有用な 方法となると期待できる。しかしながら、 $\alpha$ 選択的グリコシ ル化反応は、糖鎖の化学合成において問題の多いステップで ある。近年、 5 位のアセトアミド基を N,N- ジアセチル基 (22)、 アジド基 (23)、N-TFA 基 (24)、N-Troc 基 $(25,26) 、 N-F m o c$ 基 (26) 、N-トリクロロアセチル基 (26)、または、N- フタロイル基 (27) に変換したシアル酸糖供与体が高い反応性を示すことが明ら かになってきている。スキーム 6 は、我々が行なった 5 位変 換型シアル酸等供与体 37a-i のシアリル化反応の比較結果を示 している (26a,b)。最終脱保護工程を考慮すると、シアル酸含 有糖アミノ酸の合成には、アミノ酸をラセミ化させることな くアセトアミド基へと変換可能な N-Fmoc および N-Troc 型シ アル酸糖供与体 37d, 37e が有用であると考えられる。スキー ム 7 には、N-Troc 型シアル酸糖供与体 $37 \mathrm{e}$ を利用したシアル 酸含有糖鎖のワンポット合成を示した (26b)。N-Troc 型チオシ アリル糖供与体 $37 \mathrm{e}$ は、フッ化ガラクトシド 42 の 3 位へ化学 選択的にグリコシル化することが可能である。また、得られ たフッ化糖 44 を連続的に活性化することにより、目的とする 直鎖 3 糖 41 のワンポット合成に成功した。このような立体選 択的かつ化学選択的な $a$ シアリル化反応は、樣々なシアル酸 含有糖鎖合成の中間体合成にも有用な方法である(スキーム 6
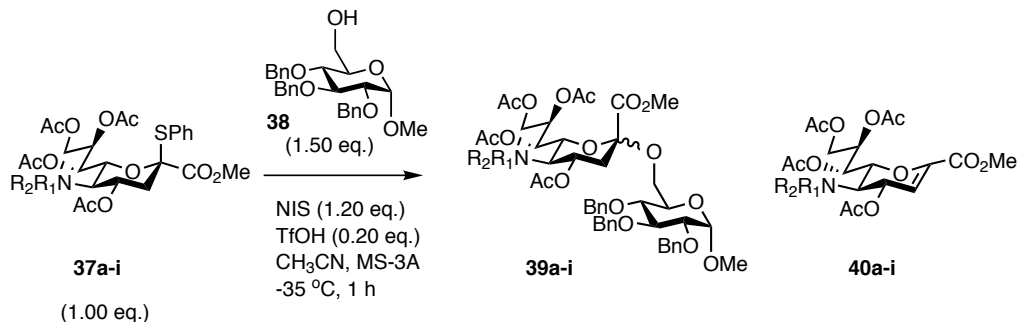

(1.00 eq.)

\begin{tabular}{lccc}
\hline Donor & $\mathrm{R}_{2} \mathrm{R}_{1} \mathrm{~N}$ & 39, Yield $/ \%(\alpha / \beta)$ & $\mathbf{4 0}$ \\
\hline 37a & ZHN & $68(84 / 16)$ & 8 \\
37b & $\mathrm{AOCHN}$ & - & - \\
$\mathbf{3 7 c}$ & $\mathrm{BocHN}$ & $44(88 / 12)$ & 20 \\
$\mathbf{3 7 d}$ & $\mathrm{FmocHN}$ & $91(86 / 14)$ & 7 \\
$\mathbf{3 7 e}$ & $\mathrm{TrocHN}$ & $91(89 / 11)$ & 6 \\
$\mathbf{3 7 f}$ & $\mathrm{TFAHN}$ & $92(92 / 8)$ & 5 \\
$\mathbf{3 7 g}$ & TCAHN & $83(91 / 9)$ & 4 \\
$\mathbf{3 7 h}$ & $\mathrm{AcHN}$ & $47(85 / 15)$ & 28 \\
$\mathbf{3 7 i}$ & Ac $\mathrm{N}$ & $65(62 / 38)$ & 23 \\
\hline
\end{tabular}

Scheme 6. Glycosidation of N-modified sialyl donors 37a-i.

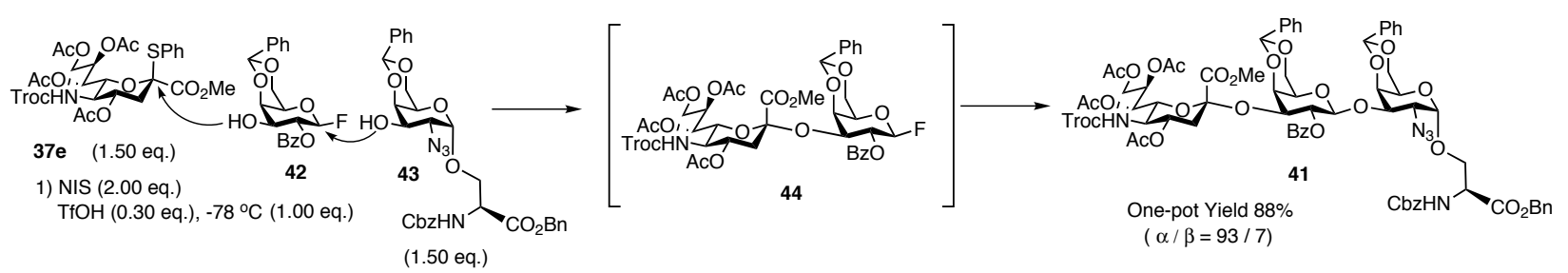

Scheme 7. The synthesis of the sialo-containing linear trisaccharide by one-pot sequential glycosylation. 
of various sialo-containing oligosaccharides.

\section{Automated Synthesis of a Protected Oligosaccharide Iibrary Based on Dimeric Lewis X Derivatives}

Development of automated technology for the synthesis of oligosaccharides is an important development in the field of carbohydrate organic chemistry. One-pot glycosylation allows the synthesis of oligosaccharides from simple building blocks by addition of only the substrates and reagents. If the requisite manipulations of one-pot glycosylation could be adapted for use with an automated synthesizer, it would be an attractive way for automated synthesis of structurally complex oligosaccharides. Scheme 8 shows an automated synthesis of dimeric Lewis $\mathrm{X}$ derivatives by one-pot glycosylation utilizing an automated synthesizer (28). One-pot glycosylation for the synthesis of the tetra- to octa-saccharides 46 was initiated by chemo- and regio-selective glycosylation of the 2-N-phthaloyl thioglucosamine $\mathbf{4 5}$ at the $\mathrm{C} 4$ position with the galactosyl fluoride A2 or A3. Activation of the resulting thioglycoside for coupling with the glycosyl acceptor B1 or B2, followed by $\alpha$-selective glycosylation of the remaining C3 hydroxyl group of the glucosamine unit with thiofucoside C provided the protected oligosaccharides $\mathbf{4 6}$ in one-pot. The use of glucosamines, A3, B1-B2, and C enabled the synthesis of the di- to tetra-saccharides 47. An automated synthesizer $\left(\mathrm{L}-\mathrm{COS}^{\mathrm{TM}}\right)$, which allows for controlled stirring, reaction temperature, and rate of reagent addition, was used in the library synthesis (Fig. 1) (29). Fig. 1 shows the program schedule for the parallel synthesis of twelve oligosaccharides 46 and 47. The program run time was eight hours, after setup of all reagents. Purification of the twelve crude compounds and 7)。

D. ダイメリックルイス X 類縁体ライブラリーの自動合成

糖鎖の自動合成法の開発は、糖質合成化学における重要な 課題の一つである。ワンポットグリル化反応は、試薬および、 基質の連続的な投入という簡便な操作だけで、簡単なユニッ 卜より、オリゴ糖の合成を可能にする。もし、これらの反応 操作を自動合成装置で行なうことができれば、複杂倠な糖鎖の 自動合成法となりうる。スキーム 8 にワンポットグリコシル 化反応を利用したダイメリックルイス X 類縁体ライブラリー の自動合成について示している (28)。ダイメリックルイス X 類縁体 46 は、2 位をフタルイミドで保護したチオグルコサミ ン 45 の 4 位に対するフッ化糖 A2,A3 の位置及び化学選択的な グリコシル化、続く、チオ糖の糖受容体 $\mathrm{B} 1, \mathbf{B} 2$ へのグリシル 化、最後に、残ったグルコサミンの 3 位水酸基にフコースユ ニット C を導入することにより達成した。ルイス X 類縁体 47 は、ブロモ糖をフッ化糖の代わりに用いることで合成できる。 図 1 に、自動合成装置と光のプロトコールを示す。本研究で 用いたモリテックス社製自動合成装置 (L-COS) は、40 種類の 反応容器について、かくはん、反応温度、試薬の分注を制御 できる。プロトコール図において、矢印は、試薬の分注を示し、 下部に光の時の反応温度を示した。当研究室では以前、本自 動合成装置を利用した糖鎖の並列合成について報告している (29)。本プログラムの実行には、8 時間を要した。反応終了後、
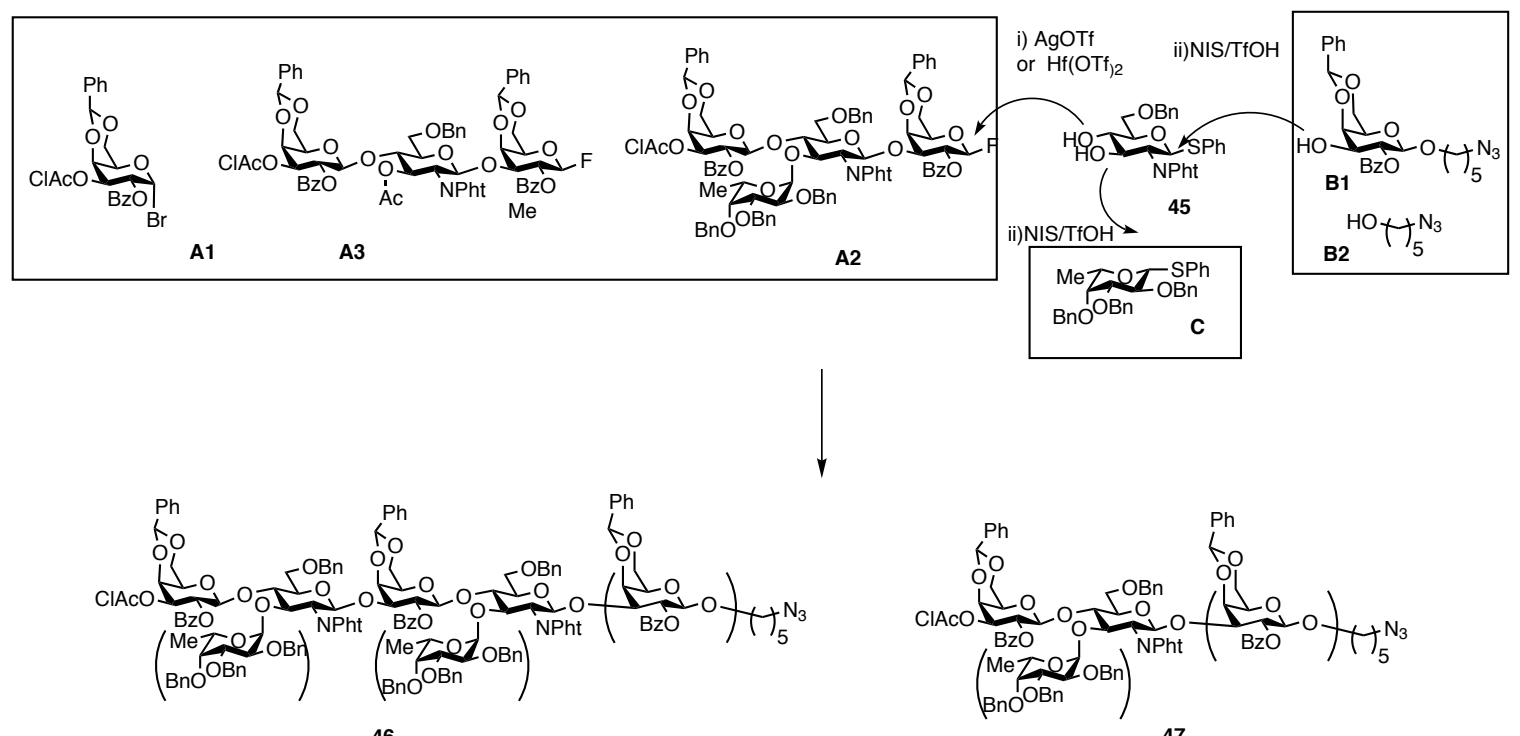

$\downarrow$

Scheme 8. The synthesis of the dimeric Lewis $\mathrm{X}$ epitope family by one-pot sequential glycosylation. 


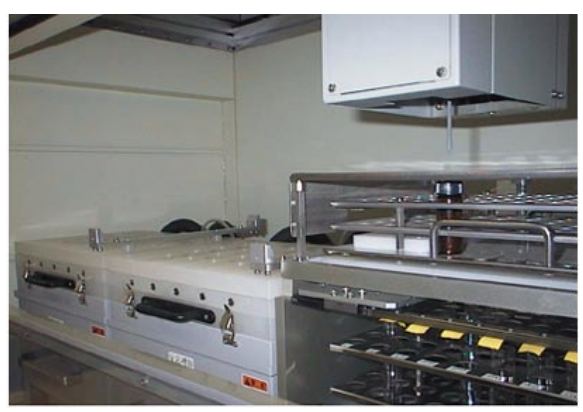

MORITEXL-COS

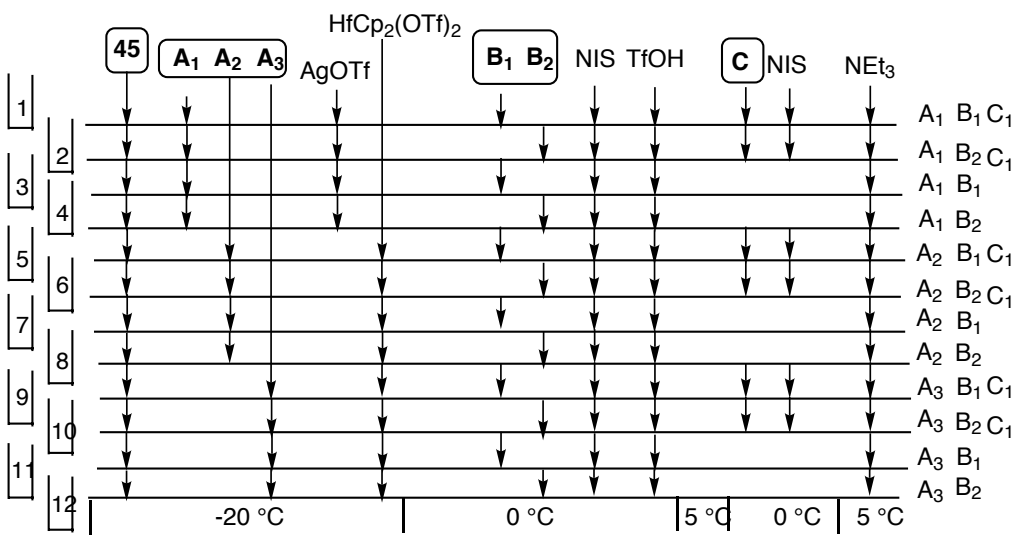

Fig. 1. The automated synthesizer (L-COS) and the program for the library synthesis.

using silica gel chromatography and gel permeability chromatography provided twelve protected oligosaccharides 46 and 47 in 22-46\% overall yields based on B1 or B2.

\section{E. Polymer-Assisted Strategy for Deprotection of Protected Oligosaccharides}

Deprotection of the protected oligosaccharides 48 to 52 , including the cleavage of various $O$-protecting groups and the replacement of $N$-protecting groups with $\mathrm{N}$-acetyl groups is the final process in oligosaccharide synthesis (Scheme 9). Complete deprotection of protected oligosaccharides frequently requires tuning the reaction solvents to prevent precipitation of partially deprotected intermediates. In addition, isolation and purification of the highly polar intermediates often results in loss of compounds. To overcome these problems, a polymer-assisted method for the deprotection of protected oligosaccharides was developed (30). The solid-supported protected oligosaccharide 51 linked through a tetrahydropyranyl (THP) linker was designed as a key intermediate. The solid-supported complex oligosaccharides smoothly undergo deprotection because aggregation is very limited. A Birch reduction was used to remove the solid-supported benzyl ethers and esters on $\mathbf{5 1}$ (31). The THP linker survived under the strongly basic conditions for deprotections and was cleaved under mildly acidic
反応溶液を濃縮、得られたクルードを精製することによって、 目的とする糖鎖を収率 22-46\% で得た (スキーム 8 and 図 1)。

\section{E. 固相法を用いる保護糖鎖の脱保護法の開発}

樣々な水酸基の保護基および、アミノ基の保護基の N- ア セチル化への変換を含む保護糖鎖の脱保護 $(48$ to 52 ) は、糖 鎖の化学合成の最終段階である (スキーム 1)。糖鎤の完全脱保 護行程では、弚の反応中間体が、反応中に凝集しないよう反 応溶媒を調整することが必要となる。合成中間体の凝集性は 構成する単糖の種類および、結合順序、光して保護基の組み 合わせに依存するため、反応条件だけでなく、脱保護の順番 も化合物ごとに注意深く調整する必要がある。さらに、複数 種類の保護基を脱保護する場合、弚の各々の段階で得られる 高極性な合成中間体の単離や精製にロスが含まれる。これら の問題を解決すること目的として、我々は、固相法を用いる 脱保護法の開発を行なった。(30) 本脱保護法では、固相上に テトラヒドロピラニルリンカーを介して結合した保護糖鎖 51 が、鍵中間体である。固相上に担持された糖鎖は凝集しにく いので、脱保護がスムーズに進行すると期待した。ベンジル エーテルや、エステルの脱保護には、Birch 還元を利用するこ

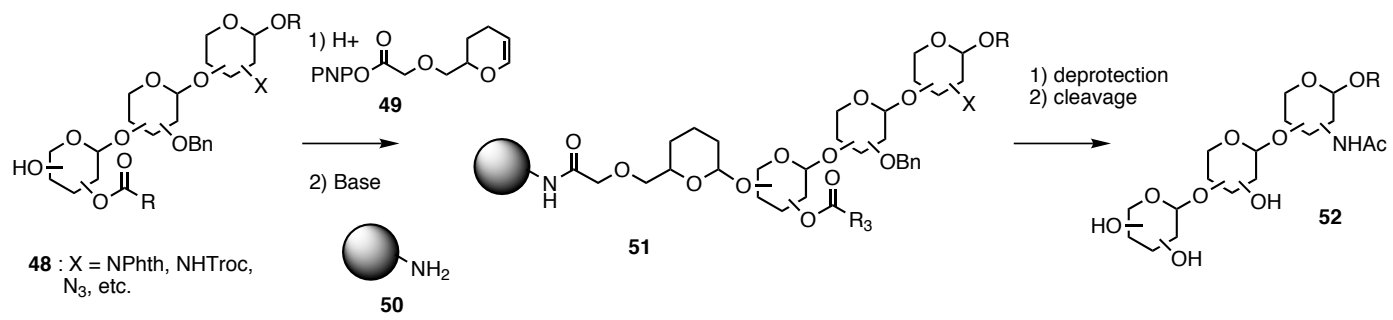

Scheme 9. Solid-assisted strategy for the deprotection of protected oligosaccharides. 
conditions to release the fully deprotected oligosaccharide 52 without anomerization or cleavage of the glycosidic bonds (32). Solid-supported compounds are easy to handle, making them effective, not only for high-speed synthesis of a single target oligosaccharide, but also for deprotection of protected oligosaccharide libraries $(13,33)$. The polymersupported protected oligosaccharide $\mathbf{5 1}$ can be prepared using the following reaction sequence: (i) acetal formation of the protected saccharides $\mathbf{4 8}$ that possess at least a hydroxyl group with the prelinker 49 containing a DHP moiety and an activated ester; and, (ii) subsequent amidation of the resulting activated ester with the solid-supported amines $\mathbf{5 0}$ to give 51, in an irreversible reaction. The irreversible loading reaction enables complete immobilization of the protected oligosaccharides 48 (34).

Scheme 10 shows the deprotection method applied to the synthesis of the protected trimeric Lewis X epitope 55 based on the polymer-assisted strategy (Scheme 4). The treatment of the protected decasaccharide $\mathbf{5 3}$ with 3 equivalents of the prelinker 49 in the presence of CSA at room temperature, followed by loading onto the resin using 10 equivalents of the solid-supported amine $\mathbf{5 0}$ provided the solid-supported oligosaccharide 54. Completely deprotected trimeric Lewis X epitope $\mathbf{5 5}$ in $\mathbf{5 8 \%}$ overall isolated yields based on 53 resulted from the following reaction sequence:
ととした (31)。THPリンカーは、これらの脱保護反応に安定で、 かつ、グリコシド結合の異性化や、切断なく固相上より切り 出すことを可能にする (32)。固相上に化合物を固定化し、取り 扱いを容易にすることは、糖鎖の迅速合成だけでなく、多種 類の糖鎖の並列脱保護にも有用であると考えられる $(13,33)$ 。 THPリンカーで固定化された糖鎖 51 は、デヒドロピランと活 性化エステルから構成されるプレリンカー49 を用いて、液相 でのアセタール化、続く、固相上のアミン $\mathbf{5 0} へ$ へアミド化に よって調製する。後者は、不可逆反応にであるので、液相法 で合成した糖鎖を効率的に固定化できると期待した (スキー 厶 10) (34)。

スキーム 10 は、固相脱保護法を用いたトリメックルイス X 55 の脱保護について示している。保護された 10 糖 $\mathbf{5 3}$ を 3 当量のプレリンカー 49 と酸性条件下反応させた。続いて、塩 基性条件下、10 当量の固相上のアミン 50 とのアミド化によ り固相上に保護糖 54 を合成した。エタノール溶媒中ヒドラジ ンを作用させることにより、フタロイル基を除去し、続いて、 遊離のアミンをアセトアミドへと変換した。続いて、Birch 還 元条件下、ベンジル基、ベンジリデンアセタール、および、 エステルを脱保護した。最後に、固相からり切り出すことに
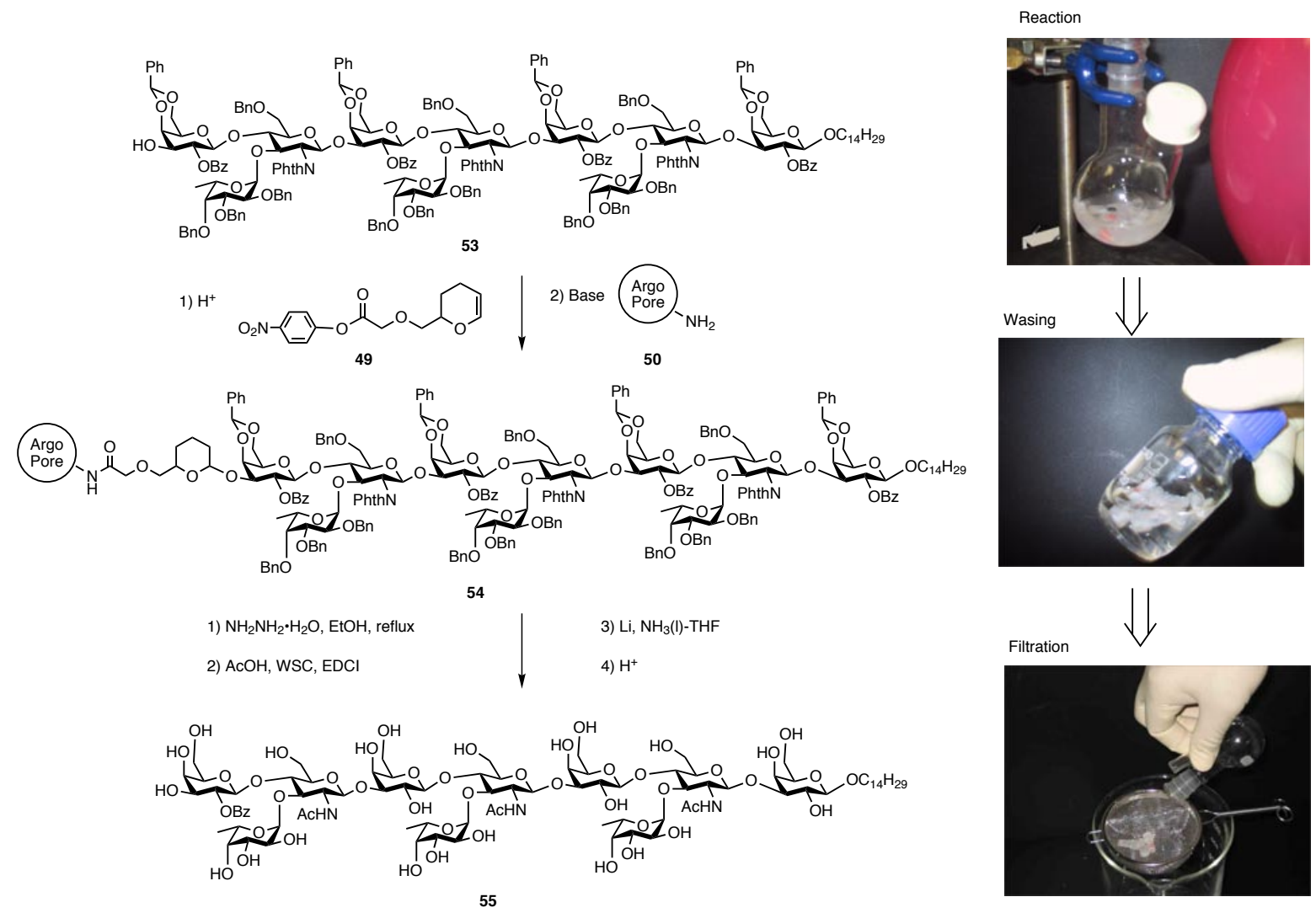

Scheme 10 The deprotection of the protected trimeric LewisX based on the solid-assisted strategy. 
removal of the phthaloyl groups of the solid-supported oligosaccharide 54; acetylation of the resulting amines; cleavage of benzyl ethers, benzylden acetal, and esters under Birch reduction conditions; cleavage from the resin under mildly acidic conditions. . ArgoPore resin was critical for the quantitative cleavage of solid-supported benzyl ethers from the solid.

\section{F. Conclusion}

In this study, biologically important oligosaccharides were synthesized in a one-pot glycosylation and a polymerassisted deprotection method was developed. These methods may be effectively applied not only to the high-speed synthesis of a single target oligosaccharide, but also to the synthesis of oligosaccharide libraries. These chemically synthesized oligosaccharides will facilitate the study of the biological functions of oligosaccharides. Although well-trained organic chemists are required for preparation of the requisite building blocks, automated lab equipment will increase the availability of these chemicals.
より目的とする 10 糖脱保護体 $\mathbf{5 5}$ を保護糖 $\mathbf{5 3}$ を基準として収 率 $58 \%$ で得た。切り出した化合物を ${ }^{1} H N M R$ によって分析し たところ、残存するベンジルエーテルは確認されなかった。 また、固相上のベンジルエーテルのBirch 還元による切断は、 A rgoPoreレジンを用いた場合に、効率的に進行した（スキー $\triangle 10)$ 。

\section{F. 結 論}

本総説では、当研究室で開発してきたワンポットグリコシ ル化反応と固相脱保護法による生物活性糖鎖の合成について 述べている。これらの方法は、標的糖鎖の迅速合成だけでなく、 糖鎖ライブラリー構築に有用な手法である。これらの化学的 に合成されたオリゴ糖鎖は、光れらの機能解明研究に大きく 寄与すると思われる。現段階では、誘導体合成に必要な糖鎖 ユニットの合成には、いまだ熟練した有機合成化学者が必要 であるが、この問題については、ラボオートメション技術に よって、将来的には解決されていくであろう。

\section{謝 辞}

本研究は、高橋研究室の学生諸氏の昼夜を問わないたゆま ない努力と研究に対する情熱の上に成し遂げられたものであ る。ここに深く感謝申し上げます。

\section{References}

1. (a) Varki, A.(1993) Glycobiology 3, 97. (b) Dwek, R. A. (1996) Chem. Rev. 96, 683. (c) Hakomori, S. (2004) Arch. Biochem. Biophys. 426, 173. (d) Bucior, I., and Burger, M. M. (2004) Curr. Opin. Struct. 14, 631

2. Seeberger. P. H. and Haase, W.-C. (2000) Chem. Rev. 100, 4349

3. Plante, O. J., Palmacci, E. R., and Seeberger, P. H. (2001) Science 291, 1523

4. Raghavan, S., and Kahne, D. (1993) J. Am. Chem. Soc. 115, 1580

5. Ley, S. V., and Priepke, H. W. M. (1994) Angew Chem., Int. Ed. Engl. 33, 2292

6. (a) Zhang, Z., Ollmann, I. R., Ye, X.-S., Wischnat, R., Baasov, T., and Wong, C,-H. (1999) J. Am. Chem. Soc. 121, 734. (b) Ye, X.-S., and Wong, C.-H. (2000) J. Org. Chem. 65, 2410

7. Yamada, H., Harada, T., Miyazaki, H., and Takahashi, T. (1994) Tetrahedron Lett. 35, 3979

8. Chenault, H. K., and Castro, A. (1994) Tetrahedron Lett. 35, 9145

9. Yamada, H., Kato, T., and Takahashi, T. (1999) Tetrahedron Lett. 40, 4581

10. Takahashi, T., Adachi, M., Matsuda, A., and Doi, T. (2000) Tetrahedron Lett. 41, 2599

11. (a) Doi, T, and Takahashi, T. (1991) J. Org. Chem. 56, 3465. (b) Takahashi, T., Tanaka, H., Yamada, H., Matsumoto, T., and Sugiura, Y. (1996) Angew. Chem., Int. Ed. 35, 1835. (c) Takahashi, T., Tanaka, H., Yamada, H., Matsumoto, T., and Sugiura, Y. (1997) Angew. Chem., Int. Ed. Engl. 36, 1524

12. (a) Takahashi, T.; Tanaka, H.; Matsuda, A., Doi, T., and Yamada, H. (1998) Bioorg. Med. Chem. Lett. 8, 3299. (b) Takahashi, T., Tanaka, H., Matsuda, A., Doi, T., Yamada, H., Matsumoto, T., Sasaki, D., and Sugiura, Y. (1998) Bioorg. Med. Chem. Lett. 8, 3303

13. Matsuda, A., Doi, T., Tanaka, H., and Takahashi, T. (2001) Synlett, 1101

14. (a) Sharp, J. K., Valent, B., and Albersheim, P. (1984) J. Biol. Chem. 259, 11312. (b) Sharp, J. K., McNeil, M., and Albersheim, P. (1984) J. Biol. Chem. 259, 11321. (c) Sharp, J. K., Albersheim, P., and Lindberg, B. (1984) J. Biol. Chem. 259, 11341

15. Yamada, H., Harada, T., and Takahashi, T. (1994) J. Am. Chem. Soc. 1994, 116, 7919

16. Yamada, H., Takimoto, H., Ikeda, T., Tsukamoto, H., Harada, T., and Takahashi, T. (2001) Synlett 1751

17. Tanaka, H., Adachi, M., Tsukamoto, H., Ikeda, T., Yamada, H., and Takahashi, T. (2002) Org. Lett. 4, 4213

18. Tanaka, H., Adachi, M., and Takahashi, T. (2004) Tetrahedron Lett. 45, 1433

19. For intermolecular aglycon transfer of thioglycoside, see: (a) Coutant, C., and Jacquinet, J.-C. (1995) J. Chem. Soc., Perkin Trans. 1 1573. (b) Leigh, D. A., Smart, J. P., and Truscello, A. M. (1995) Carbohydr. Res. 276, 417. (c) Belot, F., and Jacquinet, J.-C. (1996) Carbohydr. Res. 290, 79. (d) Biao, H. Y., Wu, X., Hui, Y., and Han, X. J. (2000) Chem. Soc., Perkin Trans. 11445. (e) Zhu, T., and Boons, G.-J. Carbohydr. Res. 329, 709

20. Recently, 2,6-dimethylphenylthioglycosides were effective for preventing the aglycon transfer, see: Li, Z., and Gildersleeve, J. C. (2006) J. Am. Chem. Soc. 128, 11612.

21. (a) Hashimoto, S., Hayashi, M., and Noyori, R. (1984) Tetrahedron Lett. 25, 1379. (b) Kunz, H., and Sager, W. (1985) Helv. Chim. Acta. 68, 283. (c) Yoshizaki, H., Fukuda, N., Sato, K., Oikawa, M., Fukase, K., Suda, Y., and Kusumoto, S. (2001) Angew. Chem., Int. Ed. 40, 1475 
22. Demchenko A. V., and Boons, G.-J. (1998) Tetrahedron Lett. 39, 3065

23. Yu, C.-S.; Niikura, K., Lin, C.-C.; Wong, C.-H. (2001) Angew. Chem., Int. Ed. 40, 2900

24. (a) Meo, D., Demchenko, A. V., and Boons, G.-J. (2001) J. Org. Chem. 66, 5490 (b) Demchenko, A. V., and Boons, G. J. (1999) Chem. Eur. J. $\mathbf{5}, 1278$

25. (a) Ando, H., Koike, Y., Ishida, H., and Kiso, M. (2003) Tetrahedron Lett. 44, 6883. (b) Ando H, Koike Y, Koizumi S, Ishida H, Kiso M. (2005) Angew. Chem., Int. Ed. 44, 6759

26. (a) Adachi, M., Tanaka, H., and Takahashi, T. (2004) Synlett 609. (b) Tanaka, H., Adachi, M., and Takahashi, T. (2005) Chem. Eur. J. 11, 849. (c) Tanaka, H., Nishiura, Y., Adachi, M., and Takahashi, T. (2006) Heterocycles 67, 107

27. Tanaka, K., Goi, T., and Fukase K. (2005) Synlett 2958

28. Tanaka, H., Matoba, N., Tsukamoto, H., Takimoto, H., Yamada, H., and Takahashi, T. (2005) Synlett 824

29. We have reported on the parallel synthesis of a oligosaccharide library utilizing the automated synthesizer, see; Tanaka, H., Amaya, T., and Takahashi, T. (2003) Tetrahedron Lett. 44, 3053

30. Tanaka, H., Ishida, T., Matoba, N., Tsukamoto, H., Yamada, H., and Takahashi, T. (2006) Angew. Chem., Int. Ed. 45, 6349

31. The solid-supported benzyl ethers are known to be difficult to cleave. (a) Kanie, O., Grotenbreg, G., and Wong, C.-H. (2000) Angew. Chem., Int. Ed. 39, 4545. (b) Adinolfi, M., Barone, G., Iadonisi, A., and Schiattarella, M. (2001) Tetrahedron Lett. $42,5971$.

32. Thompson, L. A., and Ellman, J. A. (1994) Tetrahedron Lett. 35, 9333

33. Tanaka, H., Zenkoh, T., Setoi, H., and Takahashi, T. (2002) Synlett 1427

34. Meseguer, B., Alonso-Díz, D., Griebenow, N., Herget, T., and Waldmann, H. (1999) Angew. Chem. Int. Ed. 38, 2902

Received on June 15, 2007, accepted on July 31, 2007

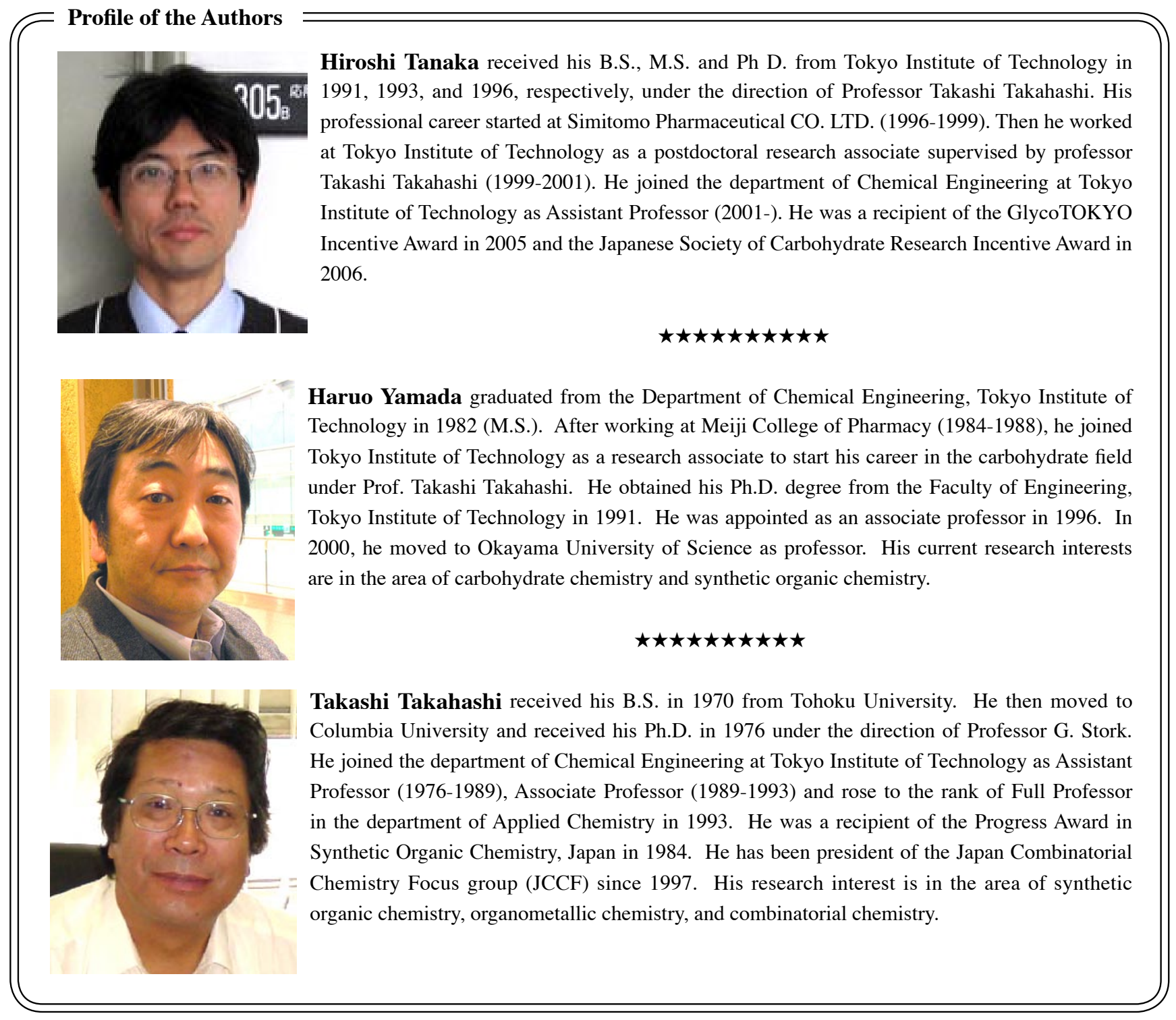

